\title{
Mütareke Döneminde İngilizlerin Elindeki Türk Esirlerinin İadesi ve Ortaya Çıkan Sorunlar
}

\author{
Doç. Dr. Selçuk URAL"
}

\section{ÖZET}

I. Dünya Savaşı, Osmanlt-Ingiliz mücadelesinde karşılıklı olarak yüz binlerce esirin verildiği bir mücadeleydi. Irak, Suriye, Filistin ve Çanakkale cephelerinde yaptlan muharebelerde Ingiliz ordusu, yüz bin civarında Türk askerini esir etti. Bunların büyük kısmı savaş boyunca Mısır'daki kamplarda tutuldu. Savaşın bitmesine bağll olarak Türk hükümeti esirlerin iadesi için girişimlerde bulundu. Ingiliz hükümeti, öncelikle yaralı ve hasta esirleri gönderdi. Bunların sevkıyatın diğer esirlerin iadesi izleyecekti.

Bu çalışmada Türk hükümetinin iade edilen esirlere yönelik hazırlıklart ve faaliyetleri konu edilmiştir.

Anahtar Kelimeler: Mondros Mütarekesi, Esir, Misır, İzmir, İstanbul

The Return of Captives in The Hands of Britain and The Afterward-Problems During The Period of Armistice

\section{ABSTRACT}

World War I was a battle between Ottomans and Britain, in which thousands of captives were exchanged mutually. In the battles on the front-lines of Irak, Syria, Palestine and Canakkale, British troops captured around hundred thousand Turkish soldiers. Most of them were kept in the concentration camps in Eygpt during the war. After the war, the Turkish goverment attempted to return captured Turkish soldiers back to Turkey. At first, the British government sent back particularly sick and wounded soldiers, and it would send other captured soldiers following their transportation.

This study focuses upon the preparation and activities of the Turkish government for the return of captured Turkish soldiers.

Key Words: Mondros Armistice, Captivities, Eygpt, İzmir, İstanbul.

* Kafkas Üniversitesi Fen-Edebiyat Fakültesi Tarih Bölümü, KARS sural25@hotmail.com. 
I. Dünya Savaşı, dünyanın ilk kapsamlı genel savaşıydı. Avrupa'nın ve diğer kıtaların büyük devletleri mevcutları milyonları bulan ordularla dört yıl boyunca birbirlerine karşı mücadele ettiler.

Bu devletlerden biri olan Osmanlı Devleti, Kafkasya'dan Çanakkale'ye, Galiçya'dan Yemen'e uzanan geniş ve çetin bir coğrafyada İtilaf Devletleri'ne karşı ölüm kalım mücadelesi verdi. Türk orduları Çanakkale, Filistin, Suriye ve Irak cephelerinde İngilizlere karşı savaştı. 1917 yılından itibaren Filistin, Suriye ve Irak cephelerinde geri çekilişe bağlı olarak sayıları yüz binleri bulan Türk askeri İngilizlere esir düştü ${ }^{1}$.

1918 yılı sonbaharında savaş Osmanlı Devleti ile ortaklarının aleyhine bir gelişme gösterdi. Ekim ayıyla birlikte başlatılan girişimlerin sonucunda 30 Ekim 1918'de Mondros Mütarekesi imzalandı. Mütareke görüşmeleri sırasında gündeme gelen konulardan biri de esirlerin karşılıklı iade edilmesiydi. İngiliz heyeti galip taraf olmanın üstünlüğünü kullanarak Osmanlı heyetinden İtilaf esirlerini en kısa zamanda iade etmesini isterken, Türk esirlerinin iadesi konusunda yükümlülük altına girmekten sakındı.

Esirlerin iadesini içeren 22. Madde, 28 Ekim günü yapılan üçüncü oturumda ele alındı. Amiral Calthorpe hükümetinin hazırladığı taslakta "Osmanlı üserası İtilaf kuvvetleri nezdinde muhafaza edilecektir" şeklinde ifade edilen ve iadeye ilişkin herhangi bir ipucu vermeyen maddeyi okudu. Rauf Bey söz alarak Türk esirlerinin de İtilaf esirleri gibi iadelerini önerdi. Öneri kabul edilmeyince 40 yaşını geçmiş olanların iadesini teklif etti. Bu da kabul edilmedi. Bunun üzerine Rauf Bey, esirlerin karşılıklı iadesini içeren Bern Antlaşması'nı ileri sürerek; “ $B$ u antlaşmayı imzalayanlar arasıında Ingilizler de vardır. Mütareke ile bu antlaşma hükümden düşmez" diyerek iade konusunda israr etti. Sonuçta maddeye "Sivil harp esirleriyle asker yaşı dışında olanların serbest bırakılmaları dikkat nazarına alınacaktır" cümlesi eklenerek kabul edildi ${ }^{2}$. Bu açıdan bakıldığında Mütarekenin 22. maddesi tek yanlı bir hüküm görüntüsü vermekteydi.

$\mathrm{Bu}$ makalenin amacı İtilaf esirlerinin tesliminin ardından İngilizler tarafından Mısır'daki Türk esirlerinin iadesi, Türk makamlarının çalışmaları ve Irak'taki esirlerin iadesine ilişkin girişimlere Genelkurmay Başkanlığı Arşivi'nden elde edilen belgeler ışığında açıklık getirmektir. Dolayısıyla makalede üç ana konu üzerinde durulacaktır:

1- Mısır'dan dönen esirlere yönelik İzmir ve İstanbul'da yapılan çalışmalar,

' Geniş bilgi için bkz: Yusuf Hikmet BAYUR, Türk Inkulâbı Tarihi, III/3, Ankara 1983, s.351-468; Enver Ziya KARAL, Osmanl Tarihi, IX, Ankara 1996, s.508-517; Lıman Von SANDERS, Türkiye'de 5 Y Yl, İstanbul 1968, s.201-355; Orhan AVCI, Irak'ta Türk Ordusu, Ankara 2004, s.149; Cemalettin TAŞKIRAN, Ana Ben Ölmedim, İstanbul 2001, s.27-38.

${ }^{2}$ Rauf ORBAY, Cehennem Değirmeni, I, İstanbul 1993, s.122; Ali TÜRKGELDİ, Moudros ve Mudanya Mütarekelerinin Tarihi, Ankara 1948, s.47 
2- Kör edilen esirlerle ilgili olarak Harbiye Nezareti'nin çalışmaları ve girişimleri

3- Irak'taki esirlerin iadesi hususunda Harbiye Nezareti'nin girişimleri.

\section{I-MISIR'DAN DÖNEN ESIRLERE YÖNELIK ÇALIŞMALAR}

Mondros Mütarekesi'nin uygulanmasıyla birlikte ilk olarak İtilaf esirlerinin iadesi için çalışma başlatıldı. Harbiye Nezareti başta olmak üzere ilgili askeri teşkilatlar kısa süre içerisinde garnizonlardaki esirleri İzmir'e naklederek İtilaf askeri temsilcilerine teslim ettiler. Hükümetin bütün imkanlarını bu işe seferber etmesi mütarekeyi uyguladığını göstermek ve aynı zamanda Türk esirlerinin iadesini gündeme getirebilmek açısından önemli addediliyordu.

Harbiye Nezareti'nin esirlere yönelik ilk girişimi Romanya cephesinde esir düșen 380 askerin Türkiye getirilmesiydi. Muharebeler sırasında 9'u subay, 371'i er olmak üzere toplam 380 asker düşmana esir düşmüştü. Harbiye Nezareti, İngilizler nezdinde girişimde bulunduktan sonra 7 Kasım 1918'de Romanya'nın Köstence şehrinde bulunan Osmanlı temsilciliğini esirlerin İstanbul'a sevk etmekle görevlendirdi ${ }^{3}$.

İngilizlerle yapılan görüşmelerde İtilaf esirlerinin iadesinin Türk esirler için dikkate alınacak bir husus olduğu ortaya çıkmıştı. Zira 2. Ordu Komutanlığı ile Suriye'deki İngiliz makamları arasında yapılan görüşmelerde, İngiliz tarafının ilk safhada yaralı ve hasta esirleri İzmir'e nakletmek kararında olduğu anlaşıldı. 2. Ordu Komutanı Nihat Paşa da 17 Kasım 1918'de Erkân-1 Harbiye-i Umumiye Riyaseti'ni bilgilendirerek ordunun terhis edildiği bir dönemde esirlerin İzmir'e sevkinin ulaşımda çeşitli sorunlar doğuracağına dikkat çekti ${ }^{4}$.

Aynı gün de İngiliz irtibat subayı Chilton, Harbiye Nezareti'ne sunduğu yazıda; hükümetinin Türk esirlerinin iadesi için limanın güvenliği ve Mısır'a yakınlığı nedeniyle İzmir'i uygun bulduğunu belirterek, önlemlerin buna göre alınmasını talep etti ${ }^{5}$. Belgelerden anlaşıldığı üzere yaralı ve hastaları ihtiva eden ilk esir kafilesinin Kasım ortalarında İzmir'e ulaştı. 4. Kolordu Askere Alma Heyeti Başkanı Albay Süleyman Fethi Bey, Harbiye Nezareti'ne gönderdiği telgrafta Foça'ya çıkarılan Türk esirlerinin İzmir'e nakledilerek her türlü ihtiyaçlarının karşılandığını bildiriyordu ${ }^{6}$.

1919 yılında ilk esir kafilesi 2 Ocak'ta Empire adlı vapurla getirildi. Beyrut'tan geldikleri anlaşılan esirler, 17. Kolordu Komutanlığı tarafından ihtiyaçları giderildikten sonra 9 Ocak'ta memleketlerine gönderildi ${ }^{7}$.

${ }^{3}$ Genelkurmay Başkanlığı Askeri Tarih ve Stratejik Etüt Dairesi Başkanlığı Arşivi İstiklâl Harbi Kataloğu (ATASE, İH) K.206, G.131, B.131-1.

${ }^{4}$ ATASE, ISH, K.206, G.137, B.137-4.

${ }^{5}$ ATASE, ISH, K.206, G.137, B.137-5.

${ }^{6}$ ATASE, ISH, K.206, G.121, B.121-1.

${ }^{7}$ ATASE, ISH, K.37, G.3, B.3-1; ATASE, ISH, K.37, G.11, B.11-1. 
Mısır'daki yaralı ve hasta esirlerin İzmir'e peyderpey gönderileceği anlaşılınca Erkân-1 Harbiye-i Umumiye Riyaseti 17. Kolordu Komutanlığı'na esirlerin iaşe, sağlık, giyim ve barınma gibi ihtiyaçlarını karşılamak üzere 10.000 liralık ödeneği İzmir Defterdarlığı'na gönderdi ${ }^{8}$.

Esirlere yönelik çalıșmaların barınma, iașe ve nakille sınırlı kalmayacağı Sıhhiye Reisi Muavini İbrahim Tali Bey'in 4. Kolordu Ahz-1 Asker Riyaseti Sertabipliği ile yaptığı yazışmadan anlaşılmaktadır. 2 Ocak 1919'da Sertabip Hasan Kadri Bey'e gönderilen telgrafta; meselenin önemi ve ileride belgeye ihtiyaç duyulacağından hareketle esirlerin sağlık durumunu tespit ettirmek üzere çeșitli unsurlardan oluşan bir sağlık heyetine muayene ettirmesi ve müşterek bir rapor hazırlatılmasının devletin menfaati gereği olduğu ifade edildi'. İbrahim Tali Bey, 5 Ocak'ta ifadelerde üzerinde durulması gereken ayrıntıları ise şöyle sıralıyordu:

1- İzmir'e gelen esirlerin esaretleri sırasında maruz kaldıkları muamelelerin ayrıntılı şekilde kayıt edilmelidir.

2- Sağlık personeli de aynı içerikte rapor hazırlayacaktır.

3- Mümkün olursa çeşitli unsurlardan oluşan bir heyet tarafından esirlerin sağlık muayeneleri yaptırılarak tespitler tutanağa kaydedilecektir.

4- Esirlerin esaret günlerine ait fotoğraf vs. hatıra türü belgeler toplanacaktır ${ }^{10}$.

Bu talimat doğrultusunda alınan ilk ifadelerden esirlerin çok zor şartlar altında yaşadıkları ortaya çıkınca Sıhhiye Şubesi, 19 Ocak 1919'da Erkân-1 Harbiye-i Umumiye Riyaseti'ne gönderdiği yazıda; Rusya ve Mısır'daki esirlerin her türlü yardımdan mahrum ve yardım edilmediği takdirde binlercesinin hastalık ve açlıktan öleceğini, buna meydan vermemek için devletin Kızılay ve Kızılhaç vasıtasıyla yardım etmesini ve tarafsız bir heyet sayesinde sağlık durumlarının tespit edilmesini teklif etti ${ }^{11}$. Harbiye Nezareti, 22 Ocak'ta hem Sadaret, hem de Hariciye Nezareti'ne başvurarak Sihhiye Şubesi'nin dikkat çektiği hususlarda İtilaf devletleri nezdinde girişimde bulunulmasını istedi ${ }^{12}$

İtilaf irtibat subayı Yarbay Murphy'nin 19 Ocak'ta Erkân-1 Harbiye-i Umumiye Riyaseti'ne gönderdiği yazı İtilaf devletlerinin hasta esirlere öncelik vermekte olduğunu gösteriyordu. Yarbay Murphy, sağlık durumları bir hayli bozulan ve iadeleri zorunlu hale gelen 56 esirin isim listesini vererek İngiliz heyeti tarafından İstanbul'a getirildikleri takdirde esirlerin memleketlerine iade edilip edilemeyeceği sordu ${ }^{13}$. 21 Ocak'ta verilen cevapta; esirlerin İstanbul'a getirilmesi durumunda memnuniyetle kabul

${ }^{8}$ ATASE, İSH, K. 186 , G. 204, B. 204-1.

${ }^{9}$ ATASE, ISH, K. 182 , G. 53 , B. $53-2$.

${ }^{10}$ ATASE, İSH, K.182, G.53, B.53-1.

"ATASE, ISH, K.123, G.69, B.69-2.

${ }^{12}$ ATASE, ISH, K.123, G.69, B.69-1.

${ }^{13}$ ATASE, ISH, K.123, G.68, B.68-2. 
edileceği ve Üsera Şubesi Müdürü Yüzbaşı Müşfik Bey'in de bu işe memur edildiği belirtilerek kafilenin ne zaman ve hangi vasitayla getirileceğinin bildirilmesi talep edildi ${ }^{14}$.

Esirlerin verdikleri ifadeler Mısır'daki durumun oldukça ciddi olduğunu gösteriyordu. Türkiye'ye getirilmedikleri takdirde on binlerce Mehmetçiğin ölmesi kesindi. Harbiye Nezareti, İngiliz Karadeniz Orduları Başkomutanı General Milne'nin İtilaf esirleriyle ilgili 28 Şubat 1919 tarihli tezkeresine verdiği cevapta; İtilaf devletlerinin Türk esirlerini iade etmemesinden dolayı Osmanlı devletinin iktisadi ve sosyal sorunlar yaşadığı ve İtilaf devletlerinin de esirler için önemli miktarda masraf ettiğine dikkat çekilerek iki başlı zararın ortadan kaldırılması için esirlerin tamamının veya hiç olmazsa terhis edilen askerlerin emsallerinin iade edilmesi istendi ${ }^{15}$.

10 Mart 1919'da Hariciye Nezareti'ne gönderilen yazıda başvurunun Türk ordusunun terhisi tamamlamadan bu konuda girişimde bulunulamayacağı gerekçesiyle geri çevrildiği ifade edilerek, yine de İtilaf yüksek komiserlikleri nezdinde 1 srarlı şekilde girişimde bulunulması istendi $^{16}$

Harbiye Nezareti ilerleyen günlerde girişimlerini sürdürdü. 25 Mart 1919'da General Milne'ye gönderilen bir başka yazıda; bazı gazetelerde Bulgar esirlerinin ülkelerine iadesine başlandığ 1 ve şimdiye kadar dönenlerin 11.000 'i aştığı yönünde çıkan haberlerin Türk kamuoyunu ve özellikle esir ailelerini fazlasıyla heyecanlandırdığı, esirlerin de gönderileceği yönündeki beklentileri kuvvetlendirdiğine dikkat çekilerek, Osmanlı devletinin sosyal yapısı ve kamuoyunun beklentileri göz önünde bulundurularak esirlerin bir an önce iadesi hususunda İngiliz Hükümeti nezdinde girişimde bulunulması istendi ${ }^{17}$.

\section{Esirlerin İstanbul'a Sevki ve Ortaya Çıkan Sorunlar}

25 Mart 1919'daki girișimin üzerinden iki hafta geçmişken ilk kafile İzmir'e getirildi. 17. Kolordu Komutanlığı'nın 29 Nisan'da Erkân-1 Harbiye'ye gönderdiği telgrafta bu tarihe kadar İzmir'e getirilen kafileler hakkında bilgi veriliyordu. Buna göre;

1- Türk esirleri İzmir'e Bronbel ve Brohen adlı iki vapurla nakledilmektedir. Bu güne kadar üç kafile halinde toplam 197 subay ve 1642 er getirildi. 1. kafile 11 Nisan 1919 'da 9 subay ve 156 er ile Brohen vapuruyla, 2. kafile 21 Nisan 1919 'da 92 subay ve 500 er ile Bronbel vapuruyla ve 3 . kafile 23 Nisan 1919'da 96 subay ve 543 er ile Brohen vapuruyla nakledildi.

${ }^{14}$ ATASE, ISH, K.123, G.68, B.68-1

${ }^{15}$ Harbiye Nezareti'nden General Milne'ye 10 Mart 1919 tarihli yazı (ATASE, ISH, K.123, G.86, B. 86-5)

${ }^{16}$ ATASE, ISH, K.123, G.86, B.86-4

${ }^{17}$ ATASE, ISH, K.123, G.86, B .86-2,3 
2- 5 Nisan 1919 'da 900'ü hasta ve geriye kalanların bir kısmının esirlerin eş ve çocukları olduğu halde 1.300 esirin geleceği haber verilmişse de henüz bu nakil gerçekleşmemiştir.

3- Vapurlarda görevli İngiliz subayları adı geçen vapurlarla her hafta düzenli olarak esirlerin nakledileceklerini ifade etmişlerse de bu beyanlar İzmir'deki İngiliz temsilcileri tarafından doğrulanmamıştır ${ }^{18}$.

Rapordan da anlaşıldığı üzere mütarekenin üzerinden altı ay geçmiş olmasına rağmen İngilizler ellerindeki esirlerin ancak yüzde birini göndermişlerdir. Bunların büyük çoğunluğunun hasta erler olduğu dikkate alınırsa nakil sürecinin daha da uzayacağına şüphe yoktu.

Esirlere yönelik çalışmaların İzmir ile sınırlı kalması düşünülemezdi. Çünkü İç Anadolu, Marmara, Karadeniz ve Trakyalı erlerin memleketlerine gönderilmesi ve hastaların daha iyi tedavi edilebilmeleri için İstanbul'a sevk edilmeleri gerekiyordu.

13 Nisan 1919'da 285 kişilik kafilenin İzmir'den yola çıkarılmasıyla İstanbul'da da çalışmalara hız verildi. Kafilenin karşılanması ve uygun şekilde yerleştirilmelerinden sorumlu olan İstanbul Muhafızlı̆̆ı, Deniz Sevkıyat Komisyonu ve Maçka Hastanesi Başhekimliği ile ortak çalışma başlattı. Buna göre öncelikle hastanelerin yatak kapasitesi tespit edilerek hangi hastanede ne kadar hasta ve yaralının yatırılacağı belirlendi. Arkasından sağlıklı olanların Sirkeci Sevk Komisyonu aracılığıyla Selimiye Seferi Sevk Komisyonu'na yönlendirilmeleri sağlandı. Son olarak esirlerin sevkleri için Sirkeci Sevk Komisyonu tarafından arabalar temin edildi ${ }^{19}$. Sevk Komisyonları, hastanelerin doluluk durumlarını her gün düzenli şekilde kontrol edilerek hasta kabulünde sorun yaşanmamasına çalışacaklardı ${ }^{20}$.

İstanbul'da hazırlıklar sürdürülürken, 22 Nisan'da Bandırma yoluyla İstanbul'a 200 asker sevk edildi. Erkân-1 Harbiye-i Umumiye Riyaseti Ordu Dairesi, 24 Nisan'da İstanbul Muhafızlı̆̆ı'nı durumdan haberdar ederek kafilenin Seferi Sevk Komisyonu'na teslim edilmesini emretti ${ }^{21}$.

Esirlerle ilgili çalışmalar içerisinde en önemlisi hiç kuşkusuz esarete ilişkin bilgilerin eksiksiz toplanmasıydı. Erkân-1 Harbiye, ordu komutanlıklarına gönderdiği 4 Mart 1919 tarihli genelgede; tutanaklarda bir çok eksiğin bulunduğunu, resmi belge yerine geçen ifadelerin dikkatli bir şekilde düzenlenmesini, zaman, mekan, olay ve isimlerin açık suretle yazılmasını emretti ${ }^{22}$. Erkân-1 Harbiye-i Umumiye Riyaseti, subayların da ifadelerine başvurulmasını istedi. Bu sayede günlük hayata ilişkin bilgilerin

${ }^{18}$ ATASE, İSH, K.123, G.104, B.104-2,3; ATASE, İSH, K.188, G.29, B.29-1. Erkân-1 Harbiye-i Umumiye Riyaseti, Muamelat-1 Zatiye, Üsera, Sıhhiye ve Ordu şubelerini bilgilendirerek hazırlıkların bu sayılar doğrultusunda yapılmasını emretti (ATASE, iSH, K.123, G.104, B.104-4).

${ }^{19}$ ATASE, ISH, K.375, G.121, B.121-2.

${ }^{20}$ ATASE, ISH, K.375, G.121, B.121-1.

${ }^{21}$ ATASE, ISH, K.169, G.71, B.71-1,2.

${ }^{22}$ ATASE, ISH, K.327, G.2, B.2-1. 
yanı sıra garnizonların sayısı, yeri ve buralarda tutulan subayların sayıları ve isimleri, ayrıca İngilizlerin tutum ve davranışları hakkında daha sağlıklı bilgiler elde edilmiş olacaktı. Erkân-1 Harbiye 2. Şubesi, Ordu ve kolordu komutanlıkları tarafından gönderilen tutanakların bir suretini Muamelat-1 Zatiye Müdüriyeti'ne verecekti ${ }^{23}$. Subaylarla ilişkin alınan bir başka karar da uygun birliklere tayin edilmeleriydi. İstanbul Muhafızı ve 25. Kolordu Komutanı Mirliva Said Paşa, subayların tayin ve iskanlarına ilişkin Harbiye Nezareti'ne gönderdiği 7 Mayıs 1919 tarihli yazısında; esaretten çok sayıda subayın dönmekte olduğunu, bir kısmının uygun birliklere tayin edildiğini, henüz tayin edilmeyen subayların iskanı için halen mevcut iki misafirhanenin yeterli gelmediğini, bu nedenle Selimiye kışlasının dışında başka bir yer tahsis edildiğini bildirdi ${ }^{24}$.

Yaralı ve hasta askerlerin arkasından sayıları 100.000'i bulan diğer esirlerin naklinin gündeme geleceğini öngören Harbiye Nezareti, zaman, iaşe ve memleketlerine sevk gibi hususlarda sorun yaşanmaması için kafilelerin İzmir yerine doğrudan İstanbul'a getirilmelerini daha doğru bulmaktaydı. 611 Haziran 1919 tarihleri arasında İngiliz Karadeniz Ordusu Başkomutanı General Milne ile yapılan yazışmalarda kafilelerin İzmir'e oranla daha geniş imkanlara sahip olan İstanbul'a yönlendirilmeleri durumunda herhangi bir olumsuzluğun yaşanmayacağına dikkat çekildi ve vapurların İstanbul'a varmalarından 24 saat önce haber verilmesinin yeterli olacağı vurgulandı. Fakat bu girişimden bir sonuç alınamad ${ }^{25}$.

İstanbul'daki çalışmalar sırasında esirlerin bulaşıcı hastalıklar taşıyabilecekleri ön görülerek Selimiye Kışlası'nda bir “Temizlik Merkezi” meydana getirilmişti. Eylül ayı başlarında merkezde odun kıtlığı baş gösterdi. İkmal Şubesi 3 Eylülde yeni bir kafilenin gelişini dikkate alarak Sihhiye Dairesi'nden temizlik merkezine odun temin edilmesini talep etti. İkmal Şubesi ertesi gün konuyu 25. Kolordu Komutanlığı'na ileterek sara hastalığının her tarafta hüküm sürdüğü bir dönemde odunsuzluk yüzünden askerlerin temizlenemedikleri ve memleketlerine gönderilemediklerini belirti ${ }^{26}$. Seferi Sevk Komisyonu, 8 Eylülde 3.000 askerin geldiği fakat temizlenemediğini bildirince ${ }^{27}$ İkmal Şubesi, aynı gün Sıhhiye Dairesi'ne gönderdiği yazıda odun sıkıntısının giderilmemesi durumunda müdahale edileceği uyarısında bulundu ${ }^{28}$. Seferi Sevk Komisyonu Başkanı Binbaşı Saim Bey, 8 Eylülde Ordu Dairesi'ne ve 9 Eylülde Sihhiye Dairesi'ne başvurarak sorunun çözümüne yardımcı olunmasını istedii ${ }^{29}$. Ordu Dairesi Başkanı Mirliva Ali Hilmi Paşa'nın girişimi üzerine Sıhhiye Dairesi'nden verilen cevapta; Mubayaa Komisyonu'nun Levazımat'a bağlı olmasına

\footnotetext{
${ }^{23}$ ATASE, İSH, K.100, G.25, B.25-1.

${ }^{24}$ ATASE, ISH, K.152, G.337, B.337-1.

${ }^{25}$ ATASE, ISH, K.90, G.10, B.10-1.

${ }^{26}$ ATASE, ISH, K.177, G.72, B.72-2,3.

${ }^{27}$ ATASE, ISH, K.177, G.71, B .71-1.

${ }^{28}$ ATASE, ISH, K.177, G.72, B.72-1.

${ }^{29}$ ATASE, ISH, K.177, G.80, B.80-5,6.
} 
rağmen Levazımat Dairesi nezdinde girişimde bulunularak 40.000 kilo odunun satın alınarak merkeze gönderildiğini ve ayrıca Seferi Sevk Komisyonu'nu uyarılarak bu tür istekler için Levazımat Dairesi'ne başvurulması gerektiğinin bildirildiği belirtildi ${ }^{30}$. Bu cevap üzerine Ali Hilmi Paşa, Levazımat Dairesi'ni 15 Eylül'de ikaz ederek merkezin faaliyetlerinde aksama olmaması için gerekli önlemlerin alınmasını istedi ${ }^{31}$.

Esaretten dönen askerlerin paraları kamplarda gasp edildiğinden İstanbul'a ulaştıklarında sefil bir halde bulunuyorlardı. Sevk Komisyonu, elindeki iç çamaşır, çorap ve kundurayı dağıtmış olduğundan 3. Kısım'dan yeni kafilelere dağıtılmak üzere yeterli miktarda kundura ve çorap istedi. Fakat istek depolarda malzeme kalmadı $\breve{g}_{1}$ gerekçesiyle geri çevrildi ${ }^{32}$. Bunun üzerine Sevk Komisyonu, 27 Eylül'de Ordu Dairesi'nden Selanik ve Mısır'dan dönmekte olan askerler için 5.000 çift kundura ve çorap talep etti $^{33}$. Ordu Dairesi üç gün sonra Levazımat Dairesi'ni talepten haberdar ederek ihtiyaç duyulan malzemelerin bir önce temin edilmesini istedi ${ }^{34}$.

Terhis edilen bazı askerlerin memleketlerine biran önce gitmek için esir kafilelerine sızmaya teşebbüs etmeleri üzerine Erkân-1 Harbiye-i Umumiye Riyaseti, askeri makamları uyararak esaretten döndüğünü resmi belgelerle ispat edemeyenlerle durumları şüpheli bulunanların Anadolu'ya nakledilmemelerini emretti ${ }^{35}$. Erkân-1 Harbiye, bu tür karışıklıklara son vermek ve Anadolu'ya nakliyatı kolaylaştırmak için esirlere seyahat belgesi verilmesini kararlaştırdı. 20 Temmuz 1919 'da ilk safhada 10.000 belge bastırılarak Seferi Sevk Komisyonu'na teslim edildi ${ }^{36}$.

Harbiye Nezareti, 5 Ekim 1919'da ordunun yeniden yapılanması projesi doğrultusunda esirlerin iki ay (2) ay süreyle izinli sayılmasına karar verdi. Ordu Dairesi, kararın sadece İngilizlerin gönderdiği esirler için geçerli olduğunu düşünerek Rusya'dan gelenlerin de bu kapsamda değerlendirilip değerlendirilemeyeceğini sordu. Verilen cevapta kararın Türkiye'ye dönen bütün esirleri kapsadığ 1 belirtildi ${ }^{37}$. Harbiye Nazırı Cemal Paşa, 11 Aralık 1919'da yeni bir emir yayınlayarak; barış antlaşmasının yıl sonuna kadar imzalanacağını, bu nedenle 2 aylık iznin yıl sonuna kadar uzatıldığını, bu süre içerisinde esirlerin hiçbir birlik ve teşkilatta istihdam edilemeyeceğini belirterek herhangi bir müdahaleye meydan verilmemesini istedi ${ }^{38}$. Askeri makamlar sevk sırasında herhangi bir sorunla karşılaşmamaları için esirlere matbu tezkere belgesi düzenleyecekti. Belgede askerlik hizmet süresini gösteren haneye ne kadar süre tutsak kaldığı yazılacaktı. Bu arada İtilaf

\footnotetext{
${ }^{30}$ ATASE, ISH, K.177, G.80, B.80-3.

${ }^{31}$ ATASE, İSH, K.177, G.80, B.80-1,2.

${ }^{32}$ ATASE, ISH, K.177, G.97, B.97-3.

${ }^{33}$ ATASE, ISH, K.177, G.97, B.97-2.

${ }^{34}$ ATASE, ISH, K.177, G.97, B.97-1.

${ }_{35}^{35}$ ATASE, ISH, K.172, G.44, B.44-1.

${ }^{36}$ ATASE, ISH, K. 172, G.29, B. 29-1.

${ }^{37}$ ATASE, İSH, K.100, G.32, B.32-1,2

${ }^{38}$ ATASE, ISH, K.139, G.87, B.87-1.
} 
devletleri ordularına ait elbise, eşya, malzeme ve teçhizatın askerlerin üzerinde bulundurulmamasına da dikkat edilecekti ${ }^{39}$.

İade kapsamında gündeme gelen konulardan birisi de esirlerin aileleriyle görüşmelerine kısıtlı da izin verilmesiydi. İngiliz Yüksek Komiserliği aracılığıyla Hariciye Nezareti'ne bildirilen kararda; İngiliz postanelerinin İtilaf devletlerinde bulunan Türk esirler için taahhütlü mektup kabul etmesini öngörülüyordu. Hariciye Nezareti, 27 Ağustosta Harbiye Nezareti'ni ve Posta-Telgraf ve Telefon Genel Müdürlügü’nden ilgililerin bilgilendirilmesini ${ }^{40} .17$ Eylülde Mütareke Komisyonu'ndaki Türk temsilcisi Yarbay Kemal Bey'in İngiliz temsilcisinden aldığı bilgiye dayanarak 7. Şube'ye gönderilen yazıda İngilizlerin elinde bulunan esirlere hem normal, hem de taahhütlü mektuplar gönderilebileceği ifade edilerek ilgili şubelerin ve kamuoyunun bilgilendirilmesi emredildi ${ }^{41}$.

\section{Selanik'ten Gelenler}

1919 yılı sonbaharında Misır'ın yanı sıra Balkanlar'dan da esirler gelmeye başladı. 7 Ekim 1919'da 1. Kolordu Kurmay Başkanlığı'ndan, Merkez Komutanlığı'na gönderilen emirde Selanik'ten Edirne'ye 155 esirin geleceği, bunlardan sağlığı yerinde olanların askeri misafirhaneye, hasta ve yaralıların da merkez hastanesine kabul edilmeleri istendi ${ }^{42}$. Kurmay Başkanlığı'nın talimatıyla Edirne'de konuşlandırılmış olan birlikler istasyona gelecek esirlerin nakli için ellerindeki bütün sedye ve arabaları geçici olarak İstasyon Sevk Memurluğu'na teslim etti ${ }^{43}$. Esirler 9 Ekim'de Edirne'ye ulaşt ${ }^{44}$ ve 1 . Kolordu Komutanlığı tarafından ihtiyaçları karşllanarak memleketlerine gönderildi ${ }^{45}$.

\section{İstanbul'dan Anadolu'ya Sevk}

İstanbul'a getirilen esirlerin memleketlerine deniz ve demiryolları olmak üzere iki güzergahtan gönderilmesine karar verildi. Demiryoluyla sevkıyat Anadolu Askeri Demiryolu Komiserliği'nin uhdesine verildi ${ }^{46}$. Demiryollarının İtilaf kuvvetlerinin denetiminde olması ve istasyonlardaki keyfi uygulamalar tren seferlerini yavaşlatıyordu. Fakat bunlardan daha önemlisi esirlerin işgal altındaki bölgelerden geçerken saldırıya uğramalarıydı. Zira 20 Ocak 1920'de Erkân-1 Harbiye 3. Şubesi tarafından Harbiye Nezareti'ne gönderilen yazıda; Pozantı'dan daha ileriye giden subayların Fransız ve İngiliz işgali altındaki bölgeden geçerken gerek işgal kuvvetleri gerekse azınlıklar tarafından hakarete ve bazen de saldırıya maruz kaldıkları ve bunun önlenmesi için yapılan girişimlerden sonuç alınamadığı

\footnotetext{
${ }^{39}$ ATASE, ISH, K.305, G.56, B.56-1.

${ }^{40}$ ATASE, ISH, K.242, G.77, B.77-1.

${ }^{41}$ ATASE, ISH, K. 165, G . 42, B 42-1.

${ }^{42}$ ATASE, ISH, K.293, G.85, B.85-5

${ }^{43}$ ATASE, ISH, K.293, G.85, B.85-6

${ }^{44}$ ATASE, ISH, K .286, G .79, B.79-1,2,3.

${ }^{45}$ ATASE, ISH, K.293, G.85, B. 85-8.

${ }^{46}$ ATASE, ISH, K.117, G.43, B.43-1; ATASE, ISH, K.117, G.54, B.54-1.
} 
öne sürülerek subayların ve devletin şerefinin korunması için Halep ve Diyarbakır'a gidecek olanların Ulukışla'dan itibaren karayoluyla seyahat etmeleri önerildi ${ }^{47}$. Mart ayında 40 kadar askerin Pozantı ve Gülek civarında Ermeni çeteleri tarafından şehit edilmesi önlemlerin yetersiz kaldığını gösteriyordu ${ }^{48}$.

Sevkle ilgili sorun sadece Çukurova'da yaşanmıyordu. Yunan ordusunun İzmir'i işgali Batı vilayetlerine mensup esirlerin sevkini zorlaştıran bir husus olarak gündeme geldi. 27 Ocak 1920 tarihli Yenigün gazetesi Akhisar'daki muhabirine dayanarak verdiği haberde Yunanlıların İzmir'e uğrayan Türk esirlerini tutuklayarak sevklerini engellediği ve haklarında yeniden esir muamelesi yaptığını iddia etti ${ }^{49}$. Bu haber üzerine harekete geçen Harbiye Nezareti, 27 Ocak'ta Dahiliye ve Hariciye nezaretlerine birer tezkere göndererek; haberin doğruluğu tam bilinmemekle beraber aylardır suçsuz ve savunmasız halka zulmeden Yunanlıların esirlere de benzer muameleyi reva görebileceklerine dikkat çekerek bu tür faaliyetlerin önlenmesini talep etti ${ }^{50}$. Dahiliye Nezareti incelemenin ardından 3 Mart 1920'de verdiği cevapta; haberin doğru olmadığını, bundan 8 ay önce İzmir'e gelen 95 erin sevkinin engellendiğini, fakat girişimleri sonucunda gerek bunların, gerekse sonradan geleceklerin serbestçe sevkleri hususunda güvence alındığını ve yine o tarihlerde Söke ve Kuşadalı erlerin Selçuk, Aziziye ve Balatcık istasyonlarından geri çevrildiklerini, fakat tutuklanmadıklarını belirterek sonuç itibariyle şu anda Osmanlı esirlerinin düzenli bir şekilde memleketlerine gönderildiğini bildirdi ${ }^{51}$. Harbiye Nezareti de bu doğrultuda Üsera Şubesi'ni bilgilendirerek endişe edecek ya da sevkıyatı durdurmayı gerektirecek bir durum olmadığını ifade etti ${ }^{52}$.

Deniz sevkıyatında ise Galata'daki İngiliz makamlarından vize almak gerekiyordu. Harbiye Nezareti, bu hususla ilgili olarak İngiliz İrtibat Subaylığı nezdinde girişimde bulunularak kendilerine yardımcı olunmasını istedi. İrtibat Subaylığı aşağıdaki şartlara uyulması durumunda Anadolu'ya sevkıyatın başlatılmasında bir sakınca görmedi. Buna göre;

1- Savaş esirlerinin isim cetvelleri hazırlanarak her kazadaki kişileri ihtiva etmek üzere takım takım Galata'da Merkez Rıhtım'da bulunan İngiliz "I.A.P.B." Şubesine gönderilecekti.

2- Takımlar mümkün mertebe küçük kafileler halinde olacaktı.

3- Şahsi durumlarda itiraz olunacak noktalar mevcut olmadığ İngiliz şubesince her takım müştereken vize alacaktı ${ }^{53}$.

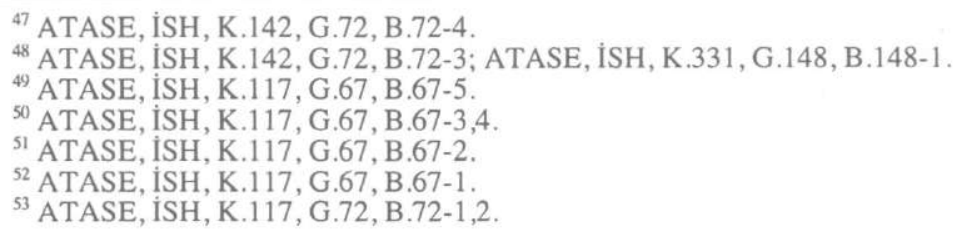




\section{Geçici Esir Müfettişliği'nin Kurulması}

Esirlerin dönüşünün zaman alması ve hizmetlerde görülen aksaklıkların giderilmesi amacıyla 12 Mayıs 1920'de Geçici Esir Müfettişliği kuruldu. Sadrazam ve Harbiye Nazırı Vekili Damat Ferit Paşa tarafından 25. Kolordu Komutanlığı, İstanbul Muhafızlığı ve Nezaretin ilgili şubelerine tebliğ edilen bildiride müfettişliğin kuruluş amacı hakkında şu bilgilere yer veriliyordu:

"1- Üseranin celb ve iskan ve ilbas ve iaşe ve sevki muamelattyla iştigal etmek üzere bir muvakkat üsera müfettişliği teşkil olunacak ve mezkur müfettiş̧liğin üseranın arkası alınıncaya kadar ifa-i vazife edeceklerdir.

"2-Müfettişliğin kadrosu ve talimatnamesi melfuftur.

"3- Üsera muamelat şubesi mezkur müfettişliğin birini şubesini teşkil edecektir. Üsera muamelat şubesi kadrosundaki sevk ve nakliyat memurlar kadrosundaki sevk ve nakliyat memurları kısmı Üçüncü şubeye verileceklerdir. Üsera muamelat şubesi kadrosundaki heyet-i sihhiye aynen müfettişlik heyet-i sihhiyesini teşkil edeceklerdir.

"4- Selimiye efrad misafirhanesi Levazımat-ı Umumiye emrinden mezkur müfettişlik emrine verilecek ve kadrosu aynen baki kalacaktır.

"5- Kadro noksanı üsera müfettişi ile muamelat-l zatiye tarafindan intihab ve tayin olunacaktır. Fazla zabitan muamelat-l zatiye emrine verilecektir.

"6- Esir zabitan maşatının tahakkuk muamelelerini ifa etmek üzre Levazımat-ı Umumiye birinci şubesiyle 25. Kolordu Levazımat'ta bu işle meşgul memurinden lïzumu miktart ikinci şubeye verilecektir" ${ }^{\text {"54 }}$.

\section{II- ESIRLERINN KÖR EDILMESİ SORUNU}

İzmir'e gönderilen yaralı ve hasta esirler arasında gözlerinden rahatsız ve hatta kör olanların sayısının fazla oluşu dikkat çekmeye başladı. İzmir'e gelen üç kafileyi kontrolden geçiren 10 kişilik bir sağlık heyeti tarafından hazırlanan 8 Ocak 1919 tarihli raporda; Misır'dan dönen kafilelerde Trahom $^{55}$ ve Oftalmi Prulent ${ }^{56}$ gibi göz hastalıklarının şiddetli bir hal aldığ birinci kafilede bir veya iki gözünü kayıp etmiş olanların sayısının 48 , ikinci kafilede 53, üçüncü kafilede ise 59'u bulduğu, bunun dişında yüzü aşkın hastanın tedavisine başlandığı, eğer tedavi olumlu sonuçlanmazsa bunların da kör olacağına dikkat çekiliyordu ${ }^{57}$. Sağlık heyeti askerlerdeki göz hastalıklarının yanı sıra zihinsel ve bedensel rahatsızlarının nedenleri hususunda esir bulundukları yerlerde iskan, giyim, iaşece pek fena şartlarda

${ }_{55}^{54}$ ATASE, İSH, K.65, G.45, B.45-1.

${ }^{55}$ Temiz olmayan ve sıcak, kuru iklim insanlarında görülen bir hastalıktır. Göz önce buğulu görmeye başlar ve bu körlüğe kadar gider. Gözde iltihaplı akıntıyla başlar göz kapağı içe dönerek zamanla körlüğü neden olur.

56 İltihaplı göz akıntısı hastalığıdır.

${ }^{57}$ ATASE, ISH, K.123, G.70, B.70-3. 
yaşamaları ile gerektiği gibi tedavi edilmemelerinin yattığını ileri sürmekteydi ${ }^{58}$.

Kör olma tehlikesiyle karşı karşıya olan askerlerin bir yandan sayısı tespit edilmeye çalışıllırken, diğer yandan da zaman geçirilmeden İzmir Merkez Hastanesi'nde tedavi edilmelerine başlandı. 13 Mart 1919'da Sıhhiye Şubesi'ne gönderilen yazıda esirlerin memleketlerine gönderilmeyerek tedavilerine başlandığı, bunlarla ilgili defterlerin de gönderildiği belirtiliyordu ${ }^{59}$.

S1hhiye Şubesi, diğer birimlerden aldığı bilgileri birleştirerek Erkân-1 Harbiye-i Umumiye Riyaseti'ne gönderdiği 14 Nisan 1919 tarihli yazıda; Mısır'dan dönen yaralı ve hasta esirlerin garnizonlarda maruz kaldıkları gayri sıhhi şartlardan ötürü \%29-30 oranında Oftalmi ve Trahom göz hastalıkları salgınına maruz kaldıkları, bunların toplam malul askerler içerisindeki oranın $\% 7$ ila 12'ye ulaştığı belirtilerek Misırdaki esirlerin sıhhi durumlarının bir an önce ıslahı lüzumu uluslar arası Sağlık Heyeti'nin raporuyla da sabit olduğuna dikkat çekti ${ }^{60}$. İngilizlerin elinde 150.000 civarında esir olduğu dikkate alınırsa göz hastalıklarından dolayı 45.000 civarında askerin kör olma riskiyle karşı karşıya kaldığı ortaya çıkmaktaydı.

Sağlıksız ortamlarda yaşama mücadelesi veren askerler hayatta kalmalarını sağlam bünyeye sahip olmalarına borçluydular. İngilizler, esirler içerisinde sağlam olanları en ağır işlerde çalıştırılırken onlara sadece ekmek ve pirinç çorbası veriyorlardı. 26. Tümen 59. Alay'da askerliğini yaparken Gazze cephesinde esir düşen Mehmet oğlu Hasan 23 Mart 1919'da verdiği ifadesinde esaret günlerini anlatırken; Tel-el Kebir garnizonunda iki ay kaldıktan sonra kendisi de dahil olmak üzere sağlamların seçilip yol yapmak ve kanaldan gelen vapurlara erzak yüklemek ve sırtlarında kum taşımak suretiyle çalıştırıldıklarını, hastalandığı güne kadar günlük 500 gram ekmek ve akşamdan akşama cüzi miktarda pirinç çorbası veya lapa verildiğini belirtmekteydi ${ }^{61}$.

Türk makamları arasında körlük vakalarının normal kabul edilemeyeceğine dair ilk ifade 5 Mayıs 1919'da Sihhiye Dairesi'ne gönderilen yazıda kendini göstermiştir. Dördüncü kafile olarak İzmir'e getirilen 3 subay ve 582 er arasında 313'ünün kör olduğu belirtilerek sayının fazlalığına dikkat çekiliyordu ${ }^{62}$. Buna rağmen yazıda herhangi bir inceleme yada girişim başlatılmasına ilişkin bir isteğe yer verilmemesi sorunun boyutları hakkında henüz bir endişenin mevcut olmadığını gösteriyordu. Fakat Nezarete ulaşan esir ifadeleri olayın arkasında bir kasıt ve ihmalin söz

${ }^{58}$ ATASE, İSH, K.123, G.70, B.70-2; Sıhhiye Şubesi'ne ulaştırılan raporun bir sureti gereği yapılmak üzere 22 Şubat 1919 'da Hariciye Nezareti'ne gönderildi (ATASE, İSH, K.123, G.70, B.70-1).

${ }^{39}$ ATASE, ISH, K. 82, G.10, B.10-2.

(6) ATASE, ISH, K. 82, G.10, B.10-1

${ }^{6}$ ATASE, ISH, K.96, G.129, B.129-1.

${ }^{62}$ ATASE, ISH, K.169, G.104, B.104-1. 
konusu olduğunu bütün çıplaklığıyla ortaya koyuyordu. Eskişehir Askerlik Şubesi Başkan vekili Yarbay İbrahim Bey, Sincanlı Askerlik şubesine bağlı 1312 (1896) doğumlu Osman oğlu Hüseyin'in ifadesine dayanarak gönderdiği telgrafta Türk askerlerinin kör edilmesinin insanlık değerleriyle bağdaşmadığına dikkat çekerek olayı şiddetle protesto ediyordu: "İngiliz ordusuna esir düşüp bilahare avdet eden Sincanlı Şubesi efradin ifadesine nazaran olbabdaki emir-i alilerine binaen şubesinden gönderilen merkumun ifadesi müteala olundukta hakikaten 20, asir medeniyeti ile gayri kabil-i telif olan hal kemal-i teessür ve teessüfle görüldü. Acaba şu ifade icab ettiği makama gönderildik de makam sahibi olmakta o millete mensup tabiiyetten dolayı kızaracak mıdır? Yoksa galibiyetin verdiği neşe ile dudak mı bükecektir, omuz mu silkecektir? Avrupa efkâr-l hissiyatında vahşi denilen Türklerin acaba hangi bir ferdi bu gibi ihanet ve cinayat irtikab etmiştir. Düvel-i mutelifeye ait hangi bir esir vatana bu surette dönmüştür..." ${ }^{13}$.

Osman oğlu Hüseyin'in dört kişilik heyet karşısında verdiği ifadesi esirlerin sistemli bir şekilde kör edildiğini gözler önüne seriyordu: “... Efendim esir düştüğüm zaman gözlerim sağlam idi. İskenderiye civarında Tel-el Kebir'de 5 numrolu tele koydular. Biz 300 kişi idik. Bir gün bizi havuz banyosuna soktular. Meğer havuzun içerisine bir takım ilaçlar koymuşlar. Havuzdan çıktıktan sonra gözlerimiz sissti, bozuldu. Sonra 7 numrolu hastahaneye yatırdılar. Bizimle esir düsmüs İslam doktorlarl orada esir bulunuyordu. Onlardan bizim gözlerimizin neden böyle olduğunu sual ettiğimizde ylkandı̆̆ınız havuza asit-i fenik gibi bazı şeyler koymuşlar ve civarımızda bulunan diğer 13.000 kişinin de bizim gibi gözlerinin bozulduğunu gördük ve anladık. Mezkûr 7 numrolu hastahanede 5 gün kaldık sonra İngiliz doktorları bizi ameliyat yapacă̆ız diyerek bayıltarak gözlerimizin bebeklerini çıkartarak bu vechile bizi gözden halel biraktılar..."64.

Beypazarı'nın Gençali köyünden Ömer oğlu Abdullah adındaki esir ifadesinde hastalığının yanı sıra kampların durumu ve günlük hayat hakkında önemli bilgiler veriyordu. Esareti boyunca Tel-el Kebir kampında kalan Abdullah, yevmiye 150 dirhem tayin ve erzakla karavana yaptıklarını belirttikten sonra hastalığı hakkında şu bilgileri veriyordu: “... Esarette iken kendiliğinden gözlerim ă̆ırmă̆a başladı. Hastahaneye düştüm. Yalnız ben değil bir çok arkadaşım da bu suretle hastalandılar... Gözlerime ilaç sürüp, ylkamak suretiyle tedavimize teșebbüs edildi. Beni ve benden başka hastahanede bulunan arkadaşlarımı bizzat bizim Türk ve Osmanlı doktorları tedaviye çaltştı. En ziyade tedavimize itina eden Osmanlı doktoru Binbaşı İbrahim Hakkı Bey olup, kendisi esaretten avdette arkadaşlarıma ve bana ellişer guruş para verdi... Göz hastahanesi 6-7 çadırdan ibaret olup bunlara da Osmanl doktoru olup rütbesini iyice bilemediğim Mustafa Bey ile evvelce ismini arz ettiğim firkamız sertabibi Binbaşı İbrahim Hakkı Bey bakıyordu.

\footnotetext{
${ }^{63}$ ATASE, ISH, K.90, G.30, B.30-3.

${ }^{64}$ ATASE, ISH, K.90, G.30, B.30-5.
} 
Muayene ve kontrolde İngiliz doktorları bulunmakta, ilaç filan vermek suretiyle tedaviye bizzat el sürmezlerdi. Ameliyat vasitasiyla gözleri çıkarmak icap edenler için Ingiliz doktorlarının emriyle bizim doktorlar hastalardan icap edenin gözünü çıkarırlardt. Ameliyata Íngiliz doktorları el sürmezdi..." ${ }^{\prime 65}$.

Bursa Askerlik Şubesi Başkanı Mehmet Bey, 2 Ağustos 1919’da Bandırma'da 7. Tümen Askerlik Şubesi Başkanlığı'na gönderdiği telgrafta esirlerin ifadelerinden yola çıkarak Ermeni doktorların esirlerin kör edilmelerinde önemli rol oynadıklarını iddia etmekteydi. Mehmet Bey, esirlerin tamamının yetersiz beslendiği ve büyük kısmının ağır işlerde çalıştırıldığına değindikten sonra göz hastalıklarına maruz kalan binlerce askerin hastanelerde Ermeni doktorlar tarafından birer bahaneyle gözlerinin çıkarıldığını öne sürdü ${ }^{66}$. Bundan önceki yazışmalarda birçok esirin ihmalkârlık nedeniyle kör olduğu açıkça dile getirilirken ilk kez bu telgrafta Ermeni doktorların rolüne değinilerek onlara yönelik suçlama yapılmış oldu.

24. Tümen Komutanlığı 58. Alay Komutanlığı'na gönderdiği ve Gazze Muharebelerinde esir düşen subaylardan Mülazim-i Evvel Halid Efendi'nin ifadesinin alınmasını isteyen telgrafta ifadelerin günü geldiğinde İtilaf devletlerine karşı kullanılacağını vurgulaması sorunun boyutlarının her geçen gün genişlediğini gösteriyordu ${ }^{67}$. Görünen o ki, ifadeler askerlerin esaret günlerini aydınlatmanın dışında, galip devletlerin uluslar arası savaş ve esir hukukuna uyup uymadıklarını ortaya çıkarmaya da hizmet edecekti. Sonuçta ister galip, ister mağlup taraf olsun devletler ellerindeki esirlere uluslar arası hukukun ön gördüğü şekilde davranmak durumundaydılar. Bu açıdan bakıldığında İngiliz hükümeti üzerine düşen yükümlülükleri yerine getirmekten uzaktı. Üstelik Türk-Ermeni ilişkilerinde yaşanan sorunları görmezlikten gelerek Ermeni kökenli doktorları Türk esir kamplarında görevlendirmeleri iyi niyetle açıklanamazdı.

20. Kolordu Sevk Komisyonu Başkanı Yüzbaşı Osman Bey'in Kolordu Kurmay Başkanlığı'na üç esire ilişkin gönderdiği yazı Tel-el Kebir garnizonundaki Ermeni tercüman ve doktorların sistemli şekilde Türk düşmanlığı yaptıklarını bir kez daha ortaya koyuyordu. Osman Bey yazısında; sağlam yapılı esirlerden savaş sonrası vatanın bir daha istifade edememesi için kasten kör edildiklerini, Tel-el Kebir garnizonunda Ermeni tercüman ve doktorların görev yaptıkları göz önünde bulundurulduğunda bu duruma şaşırılmamasını, Mısır'da göz hastalığı öteden beri mevcut olup bunun etkisiyle gözlerinden mahrum oldukları iddia edilirse orada bir süre kalan esirlerin yanı sıra yıllardan beri orada yaşamakta olan bütün halkın

${ }_{65}$ ATASE, İSH, K.90, G.32, B.32-2; Er Abdullah'ın ifadesi 27 Temmuz 1919'da Ankara 13. Tümen Askerlik Şubesi Başkanlığı'na gönderildi (ATASE, İSH, K.90, G.32, B.32-1).

${ }^{6}$ ATASE, ISH, K.96, G.136, B.136-1.

${ }^{67}$ ATASE, ISH, K.90, G.40, B. 40-1,3,5. 
gözlerini kaybetmeleri gerektiğini belirterek esirlerin kör edilmelerinde kesinlikle bir kasit olduğunu ifade etti ${ }^{68}$.

Kalecikli Mustafa oğlu Hasan'ın 10 Ağustos 1919'da verdiği ifade kötü muamelenin her kamp ve hastane için geçerli olmadığını gösteriyordu. Hasan ifadesinde; Halep'in tahliyesi sırasında gözlerinin ağrımasından dolayı hastaneye yattığını, İngilizlerin şehri işgal etmelerinden sonra ilgisizlik yüzünden rahatsızlığının arttığını, ara sıra bir Ermeni doktorun muayene ettiğini ve hastanede görevli Ermeni kızlar vasıtasıyla tedaviye çalıştığını, bu aşamada gözlerinin gördüğünü, fakat bir gün Ermeni kızlarından birinin güya yanlışlıkla tentürdiyot sürerek kör olmasına yol açtığını, Şerif Hüseyin kuvvetlerinin şehre girmesinden sonra kendilerine iyi bakıldığını söylemekteydi ${ }^{69}$.

Boyabatı Arif oğlu Mehmet Ali ifadesinde, Kandıra hastanesinde kendisi de dahil olmak üzere bütün hastaların İngiliz doktorlar tarafından muayene edildiğini, fakat tedavilerinin Arap asılll sıhhiye erlerince yapıldığını, Tel-el Kebir'e nakledildikten sonra esir Türk doktorlarından Yüzbaşı Mustafa ve Yüzbaşı İbrahim Beylerin İngiliz doktorlarıyla beraber tedavileriyle ilgilendiklerini, günde üç dört defa çeşitli renklerde (Mor, Yeşil, Sarı) üç-dört çeșit ilaç sürüldüğünü belirti. Mehmet Ali ifadesinin devamında sevk edildikleri güne kadar dışarıya çıkmalarına asla izin verilmediğini, kampa getirildiklerinde İngiliz yetkililerin paralarını senet karşılığı aldıklarını, fakat Türkiye'ye dönerken iade etmediklerini, parayı almak için birkaç defa girişimde bulunduklarını ama sonuç alamadıklarını ifade $\mathrm{etti}^{70}$.

İskilipli Mustafa oğlu Ali Çavuş ise ifadesinde; esir düştüğü andan Kandıra'ya getirildiği ana kadar gözlerinde herhangi sorun olmadığını, fakat sevk esnasında çok zahmet çektiklerini ve Kandıra'ya ulaştıktan sonra hastaneye yatırıldığını anlattıktan sonra tedavisiyle ilgili verdiği bilgilerde ilaçların işe yaramamasına rağmen İngiliz doktorlarca inatla kullanılmaya devam edildiğini belirterek, Türk doktorları Mustafa ve İbrahim Beylere başvurduklarını, doktorların da "Biz de sizin gibi esiriz verdikleri ilaç budur” demek suretiyle şikayetlerinin sonuçsuz kaldığını iddia etmekteydi. Ali Çavuş tedavileri boyunca yetirsiz beslendiklerini "Sabah ve akşam şekersiz çay ve öğleden öğleye olmak üzere yirmi dört saatte bir mercimek ve bakla verirlerdi" sözleriyle ortaya koyuyordu ${ }^{71}$.

Boyabatlı Ali oğlu Fehmi ise ifadesinde Tel-el Kebir kampında tutulan kör esirlerin sayısına ışık tutacak bilgiler veriyordu. Ali Çavuş bir çadırda 60 ila 74 esir bulunduğunu ileri sürerken, Fehmi 12 çadırın körlere tahsis

\footnotetext{
${ }^{68}$ ATASE, ISH, K.90, G.39, B.39-1.

${ }^{*}$ ATASE, ISH, K. 90, G 39 , B 39-4

${ }^{70}$ ATASE, ISH, K.90, G.44, B.44-2.

${ }^{71}$ ATASE, ISH, K.90, G.44, B.44-4,5.
} 
edildiğini ve her çadırda 100 erin kaldığını ifade etmekteydi ${ }^{72}$. Bu bilgi esas alındığında kampta 1200 civarında kör erin bulunduğu ortaya çıkmaktadır.

Er Fehmi'nin iadesini diğerlerinden daha önemli hale getiren bir başka husus daha vardı. O da bazı İngiliz doktorlarının mesleki ahlaktan yoksun davranışlar içerisinde olduklarıydı. Bir İngiliz doktorunun davranışı hakkında Fehmi ifadesinde şöyle diyordu: "İngiliz binbaşısı gelirdi, gece gözleri görür var mıdır, gözleri görüpte artık kaçacak kaldı mı içinizde diye sorardl. Demek ki hep bunlar mahsus bizi kör ettiler. Ingiliz zabiti gözümüze iyice bakar hemen ameliyathaneye yazar. Ameliyathaneye gönderildiğinde gözünün dermanını sileceğim diye kaşık gibi bir aletle onu gözüne taktı̆̆ gibi gözleri çıkarırdı. Bunlar benim gözlerim kör olmazdan evvel arkadaşlara yaptıklarını görmüştüm,"73.

20. Kolordu Komutanlığı, 3 Ağustos 1919'da 2. Ordu Müfettişliği'ne yaptığı başvuruda asker olmaktan başka kabahatleri olmayan bu zavallıların hukukunun korunması için girişimde bulunulmasını talep etti. 2. Ordu Müfettişliği de 9 Ağustos'ta gereğinin yapılması talebiyle ifadeleri Harbiye Nezareti'ne gönderdi ${ }^{74}$.

$\mathrm{Bu}$ ifadeler Ermeni tercüman ve doktorların yanı sıra İngiliz doktorlarının da müşterek hareket ederek Türk esirlerine zulmettiklerini hiçbir şüpheye yer bırakmaksızın ortaya çıkıyordu. Bu duruma tepkisiz kalmayan Harbiye Nezareti dosyayı 23 Ağustos 1919 'da İngiliz irtibat subayı Binbaşı Millence'ye ulaştırdı. Nezaret, esirlerin esaret esnasında gözlerini kaybetmelerinde Ermeni doktor ve hemşirelerinin rolüne dikkat çektiği yazısında henüz teslim edilmeyen ama erlerin tedavilerine daha fazla özen gösterilmesini talep etti ${ }^{75}$. Üslubunun yumuşaklığına rağmen yazı esirlerin kör edilmesinin iki devlet arasında önemli bir sorun haline dönüştüğünün işaretlerini veriyordu. Nezaretin elinde esirlerin kasten veya ihmal yüzünden kör edildiğine dair çok sayıda ifade bulunmasına rağmen sorunun bu şekilde dile getirilmesi Damat Ferit Hükümeti'nin dış politikada İngiltere ile yakın ilişkiler kurmak istemesinden kaynaklanmaktaydı. Bunun yanı sıra içte Kuva-yı Milliye ile siyasi mücadeleye girişmesi bu konuya ilgisiz kalmasına da yol açmıştır.

İfadelerine başvurulan subaylardan biri de Üsteğmen Vanlı Hasan oğlu Şevket Bey idi. Şevket Bey, 2 Ağustos 1919 tarihli ifadesinde esir garnizonuna götürülürken İngilizlerin acımasızca davrandıklarını ayrıntıları bir şekilde anlatmaktaydı: Ingilizler esir kafilesine ancak dördüncü gün sonra ekmek ve pestil dağıttıklar. Bir konak yerinden diğerine ulaşıncaya kadar su yüzü göstermediği için bir çok asker baygınlık geçirdi. Yolda subaylar dahil bütün esirler dipçik ve dayağa maruz kaldıkları gibi, herhangi bir asker hastalanıp yürüyemeyecek hale geldiğinde o kişi dipçik

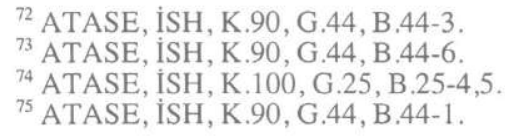


darbeleriyle öldürülüyordu. Karantina süresi içerisinde esirler şekersiz çay, soğan, şalgam ve 400 gram ekmekle karınlarını doyurmak zorunda kaldılar. Mısır'a ulaştıklarında kum deryaları üzerinde kurulmuş ve sağlıksız çadırlarda kaldıklarını ifade eden Şevket Bey, 600 kuruş maaştan 300 kuruşun iaşeye, 15 kuruşun doktora kesilerek 285 kuruşun kendilerine verildiğini, küçük bir hata yapmaları durumunda maaşın kesilerek bir ay boyunca açlığa ve susuzluğa mahkum edildiğini, ayrıca temizliğe özen gösterilmemesi yüzünden her gün bir arkadaşının çeșitli hastalıklara yakalandığını dile getirdi ${ }^{76}$.

Seydi Beşir garnizonunda kalan İzmirli Yüzbaşı Seyfettin Bey ise iașe sorununun çözümüne ilişkin bilgiler veriyordu. İngiliz makamları iaşe teminini kendileri üstlenmeyip bu işi kişi başına 300 kuruş karşılığında "Lorans" adlı bir işadamına ihale etmişlerdi. Garnizon dışına çıkmak yasaklandığından erzak, giyim vs. ihtiyaçların temininde müteahhidin keyif ve arzusuna tabi kalıyorlardı. Müteahhidin keyfi uygulamaları pek çok şikayete neden olmuşsa da bunlardan bir sonuç alınamamıştır ${ }^{77}$.

22. Tümen 128. Alay 2. Taburunda görev yapan Hesap Memuru Muavini Mehmet Nuri Efendi ifadesinde benzer sıkıntılara dikkat çekerek, Mısır gazetelerinde erzak fiyatları düzenli olarak yayınlandığı halde Lorans'ın erzakları fahiş fiyatla sattığını, İngilizlerin de değerli eşyaları gasp ettiklerini, esirlerin paralarını makbuz karşılığında aldıklarını, dönüş sırasında 87 kuruş üzerinden Mısır parası verdiklerini belirtmekteydi ${ }^{78}$.

\section{III- IRAK'TAKI ESIRLERİN İADESİ}

Mısır ve Selanik'ten Türk esirleri dönmeye devam ederken, İngilizler Irak'taki esirlerin naklini 1919 yılı eylül ayı sonlarında gündeme getirdiler. İngiliz Karadeniz Orduları Başkomutanı General Milne, 29 Eylülde Harbiye Nezareti'ne gönderdiği tezkerede konu hakkındaki planı açıkladı:

"20.000 Türk üsera-ı harbiyesinin Elcezire'den memleketlerine iade edilmek üzre bulunduklarını arz etmekle kesbi şeref eylerim. Mensup olduklarl vilayetlere nazaran gurup gurup avdet etmeleri ve iki sinifa taksim olunmalarını teklif ederim.

“A) Van, Bitlis, Diyarbakır, Elaziz'e ait olanlar,

“B) Mütebaki Türkiye'ye ait olanlar

"A sinifina ithal edilmiş olanların Cizre, B sinifina ait olanların da Dersaadet'te teslim olunmaları için tertibat-l mukteziyede bulunup bulunulmayacă̆ının iş'arını rica ederim",79.

\footnotetext{
${ }^{76}$ ATASE, ISH, K.96, G.140, B.140-1.

$n$ ATASE, ISH, K.96, G.141, B.141-1.

${ }^{78}$ ATASE, ISH, K.96, G.138, B.138-1.

${ }^{79}$ ATASE, ISH, K.100, G.32, B.32-2.
} 
General Milne'nin teklifi Harbiye Nezareti tarafından memnunlukla karşılandı. 4 Ekim'de verilen cevapta; sevkıyatın iki bölgeye bölünmek istenmesi olumlu karşılandığ karşılanması için 13. KOK Albay Cevdet Bey'e gereken emirlerin verildiği, İstanbul'a gönderileceklerin deniz yada demiryoluyla $\mathrm{m} 1$ gönderileceğinin bildirilmesi istend ${ }^{80}$. Bu hususla ilgili olarak İngiliz karargahı tarafından verilen 16 Ekim tarihli cevapta Batı vilayetlerine mensup askerlerin deniz yoluyla gönderilecekleri bildirildi ${ }^{81}$. Aslında deniz yolunun tercih edilmesi nezaretin ve diğer askeri teşkilatların yükünü artıracaktı. Demiryolu seçeneği değerlendirilseydi esirlerin ihtiyaçları 13 . KOK tarafından karşılandıktan sonra peyderpey vilayetlere sevk edilecek ve başka bir hazırlığa ihtiyaç duyulmayacaktı. Fakat İstanbul'a getirildiklerinde yeni kışlalar ve misafirhaneler bulunmak durumunda kalınacaktı.

Harbiye Nazırı Cemal Paşa, 5 Ekim'de 13. KOK ve 8 Ekim'de de 25. KOK ile Erkân-1 Harbiye-i Umumiye Riyaseti şubelerini ilgilendiren iki emir yayınladı. 5 Ekimde 6 madde halinde yayınlanan emirde aşağıdaki hususlara yer veriliyordu:

"1-Ingilizlerin taht-l esaretinde bulunan efradımızdan 20 bin nefer iade olunacak ve bunlardan Van, Bitlis, Diyarbakır, Elaziz vilayetleri halkından olanlar Cizre'de bize teslim edilecektir.

“2- Üseranın Cizre'de teslimine ve memleketlerine sevkine veyahut senelerine nazaran muamele ifasina 13. Kolordu Kumandanlığı memurdur. Bunun için kolordu mücavir Ingiliz kumandantyla derhal tesis-i irtibat etmelidir.

"3- Senelerden beri vatanlarından cüda kalan efradımızın esna-ı avdette de ziyana uğramamalarını 13. Kolordu Kumandanlı̆̆ en dakik teferruata kadar ittihaz-l tertibat etmekle temin edebilir.

“4- Harbiye Nezareti'nin Ordu, Sihhlye, Levazımat-ı Umumiye daireleriyle Üsera Muamelat Şubesi kolordu ile icabında resen muhabere ederek teferruata ait noksanlarl ve muamelatı ikmal etmelidirler.

"5- Kolordu bu üsera için cemiyet-i mülkiyenin her türlü vesaitinden istifade etmelidir.

"6- Teslim olunan kafilelerden ne miktarının memleketlerine sevk olunduğu, ne kadarının kitaata ithal olunduğu tarih zikredilerek ve tafsilaten Kolordu tarafından Erkân-ı Harbiye-i Umûmiye'ye bildirilecektir" ${ }^{\prime 2}$.

\footnotetext{
${ }^{*}$ ATASE, İSH, K.100, G.32, B.32-9.

${ }^{81}$ ATASE, ISH, K.236, G.182, B.182-1.

${ }^{82}$ ATASE, ÍSH, K.123, G.119, B.119-3; Cemal paşa aynı gün diğer kolorduları da gelişmeler hakkında bilgilendirdi (ATASE, ISH, K.123, G.119, B.119-2).
} 
25. KOK ile Erkân-1 Harbiye-i Umumiye Riyaseti şubelerinin ortak çalışmasını öngören 8 Ekim tarihli emirde ise şu hususlara değiniliyordu:

"Elcezire'den 20 bin neferimiz iade olunacă̆ İngiliz Karargâh-ı Umûmiliği'nden bildirilmiştir. Bu efrattan Anadolu vilayetleri halkı Dersaadet'te teslim olunacağından gelecek evlad-ı vatanın hiçbir tehir ve sefalete maruz kalmaması için hususat-ı atiye tebliğ olunur:

"1-Üseranın istikbal, iskan, iaşe ve memleketlerine sevk veya senelerine göre kıtaata izamları hususu ahiren teşkil ve tevsii 24/9/335 tarih ve Ordu şubesi 9/378 numro ile emir olunduğu veçhile Üsera Muamelat Şubesi'nce yapulacaktır.

"2- Her türlü malzeme tedariki hususunda şube-i mezkûrenin müracaatı alakadar devair istizana mahal verilmeksizin derhal ifa edilecektir.

"3- Üsera şubesi vürud edecek üsera meyanındaki zabitanı yedlerine vesika ita ederek muamelat-ı zatiye dairesine gönderecek ve efrad hakkında da ordu dairesinde alacă̆ talimata nazaran ifa-l muamele edecektir. Üsera arasında sivil veya memurin-i mülkiyeden olanlar devair-i mutelifesine müracaat etmek üzere serbest birakılacaktır.

“4- Üsera Muamelat Şubesi Müdüriyeti'ne 14. Furka kumandan-l sabıkı Miralay Sami Sabit Bey tayin edilmiştir. Mumaileyhe vazifesini muamelat-ı zatiye dairesi sürat-ı mümküne ile tebliği edecektir.

"5- Şube Müdürü Sami Bey'in derhal işe başlamast ve şimdiden ihzarata başlaması lazımdır" ${ }^{\prime 3}$.

Harbiye Nezareti, 9 Ekim'de Sadareti gelişmeler hakkında bilgilendirerek bütün kurumların üzerine düşen görevleri aksatmadan yerine getirmesinin önemli olduğunu vurguladı ${ }^{84}$. Bahriye Nezareti'ne gönderilen yazıda ise Mütareke komisyonunda meydana gelen görüşmeler hakkında bilgi verildikten sonra esirlerin nakli için vapur tahsisinin bir an önce çözüme kavuşturulması istendi ${ }^{85}$.

Bilindiği gibi Harbiye Nezareti, temsilcisi aracılığıyla esirlerin iadesini fırsat buldukça Mütareke Komisyonu'nun gündemine getiriyordu. 6 Ekim'de toplanan komisyonda Türk temsilcisi Yarbay Kemal Bey konuyu yeniden gündeme getirdi. 7 Ekim'de Harbiye Nezareti'ne ulaştırdı̆̆ raporunda görüşme hakkında şu bilgileri vermekteydi:

“Üsera-ı Osmaniye'nin iadesi hakkında zaten öteden beri Ingilizler nezdinde olan teşebbüsat derece-i kafiyede iyi bir akis

\footnotetext{
${ }^{83}$ ATASE, isH, K.100, G.33, B.33-4.5.6.

${ }^{84}$ ATASE, ISH, K. 100, G.33, B.33-1

${ }^{85}$ ATASE, ISH, K.100, G.33, B.33-2.
} 
bulduğu gibi ïseramızın Mısır'da bulunması kendileri için dahi bir mani olduğuna dair nazar-l dikkatleri celb edilerek bugün dahi mevzu-l bahs olmus ve tekalif-i dostaneye mukabil Ingiliz murahhast "zaten hastakân getirilmekte idi. Fakat Msır ve Hindistan'daki Üseranın miktarı ise yüz bini mütecaviz olduğundan defaten değil peyderpey nakil onulabilir" diye cevap verdi. Buna mukabil Akdeniz, Gülcemal, Reşit Paşa vapurlarının Alman, Rus üserası değil Türk üserast nakline terki teklif olundu. Mumaileyh Berlin'deki Osmanlt sefarethanesinin müttefikeyn ile akdettiği mukavele mucibince vapurlar Rus, Alman üserasi nakline tahsis olunmuştur cevabı alındt. Berlin'deki Sefarethane mülga olduğundan sefarethane-i mezkûrenin mukaveleleri esasen mefsuhtur. Hükümet-i Seniye bunu kabul etmez, denildiğinde şimdiye kadar bu babda bir müracaat edilmedi. Edilirse tabii matlub hasıl olur, cevabı alınmıştır. Binaenaleyh üsera-l Osmaniye'nin avdetleri için 18/9/35 tarihinde takdim ettiği arizada dahi tefsil ettiğim veçhile vapurlarımıza Bahriye Nezareti Celilesi tarafından tesâhüb edilmiyor ve üseramızın iadesi için bütün kuvvetimiz sarf ve istimal edilmiyor..."

Rapordan anlaşıldı̆̆ı üzere vapur tedariki mevcut sorunlar içerisinde mukayese kabul etmez bir önceliğe sahipti. Fakat yeterli vapurun olmaması ve mevcutların ise yabancı esirlerin nakline tahsis edilmesi Türk esirlerinin naklini İngiliz makamlarının insafına bırakılmasına neden oluyordu.

Üsera Şubesi, Irak'taki esirlerin iadesine ilişkin İngilizlerle bu yazışmalar sürerken kendisinin bilgilendirilmemesine tepki gösterdi. Bunun üzerine Erkân-1 Harbiye-i Umumiye Riyaseti 2. Şubesi 26 Ekim'de şubeyi bilgilendirerek hazırlıkların buna göre yapılmasını talep etti ${ }^{87}$. 2. Şube 28 Ekim'de de 13. Kolordu Komutanlığı'na gönderdiği yazıda; Cizre'de teslim edilecek esirlerin köylerine kadar muhafiz eşliğinde nakilleri ve herkesten yardım görmelerinin sağlanmasını istedi ${ }^{88}$. Bu arada Batı Anadolu ve Trakya'daki kolordular ve askerlik Şubeleri de uyarılarak esirlerin kabul ve nakillerinde herhangi bir sorun yaşanmaması emredildi ${ }^{89}$.

Türk tarafında bu hazırlıklar sürerken, General Milne'nin mektubunun üzerinden 40 gün geçmiş olmasına rağmen İngiliz tarafında herhangi bir hareket görülmüyordu. Bunun üzerine Harbiye Nezareti, 4 Kasım'da İngiliz Karadeniz Ordusu Başkomutanlığı'na yaptığı başvuruda, kışın yaklaşmasını, menzil teşkilatlarının yetersizliğini ve iç bölgelere nakillerde sıkıntılar çıkabileceğini öne sürerek sevkıyatın Cizre yerine Musul'la demiryolu bağlantısı bulunmasından dolayı Nusaybin'e yapılmasını teklif etti. 6 Kasım'da da 13. Kolordu Komutanlığı'na gönderdiği telgrafta İngilizlerin çalışmaları hakkında bilgi istendi. 13. Kolordu Komutanı Cevdet Bey, 9

${ }^{86}$ ATASE, ISH, K.100, G.33, B.33-3.

87 ATASE, ISH, K. 100 , G. 38, B . 38-2,3.

${ }^{88}$ ATASE, ISH, K.100, G.38, B.38-1.

${ }^{89}$ ATASE, ISH, K.293, G.95, B.95-1,2,3. 
Kasım'da verdiği cevapta hazırlıklar ve nakil hakkındaki görüş ve kuşkularını dile getirdi:

"Gönderilecek üseranın Musul'a bile gelmedikleri Cizre'den Zaho'ya gönderilen zabitanımızın tahkikatından anlaşılmıştır. Musul'un tahliyesi havadisleri kuvvetle deveran ettiğine göre üseranın kamilen bu tarikle iade olunacaklarına ihtimal verilmemektedir. Bundan başka kış tekarrüb ediyor. İaşe ve iskan ve nakliyat hususlarında oldukça müşkülat zuhur edecektir. Geçen sene 6. Orduca terhis olunan 16 bin neferin nakliyatı 6 aydan fazla sürmüşü̈. Bilhassa Telabriz'den itibaren hattı Fransızlar teslim etmişlerdir. Daha ziyade müşkülat çıkarmaları melhûzdur. Kumpanya tesviyede para kabul ediyor. Nusaybin'den Konya'ya kadar bir neferin ücret-i nakliyesi 490 kuruştur. Gelecek üseranın Kolorduca iaşeleri mümkündür. Nakliyat için para yoktur. Nakliyat uzarsa kışın iskan müşkül olur. Hastallk zuhur eder. Musul ile Nusaybin arasında menzil hattı ve su yoktur. 20 bin üseranın Cizre üzerinden sevki de müşüldür. Kolorduca Cizre'ye gelecek üserayı kabul etmek üzere bir komisyon gönderilmiştir. 20 bin esirin de bu tarikle geleceğine göre bu komisyonu takviye etmek Nusaybin'de yeniden bir komisyon yapmak, Cizre ve Nusaybin'e mubayaa suretle iaşe getirmek icap edecektir. Bunun için üseranın vapurla nakilleri için teşebbüsatta bulunulması ve bu mümkün olamayacă̆ı takdirde esas tertibat ittihaz edebilmekliğimiz için iade olunacak bu 20 bin esir ne vakit ve hangi tarikle iade olunacaklarının ve nerede bize teslim edileceklerinin serian ve tafsilaten işarına müsaade buyurulması maruzdur" ${ }^{\prime 0}$.

Görülüyor ki, Irak'ta değişen siyasi ve askeri şartlar esirlerin iadesini zorlaştırmaktaydı. Sevkıyat hattının henüz netleştirilmemesi, kış mevsiminin yaklaşması, para sıkıntısı ve menzil teşkilatının yetersizliği gibi konular Nezaretin çözüme kavuşturması gereken sorunlar olarak ortada duruyordu. Harbiye Nezareti, Cevdet Bey'in raporu doğrultusunda İngiliz Karadeniz Orduları Başkomutanlığı'na başvurdu, fakat 16 Kasım tarihi itibariyle bir cevap alamadı. Nezaret, Nusaybin ile ilgili teklifinin kabul edilebileceğinden hareketle 13. Kolordu Komutanlığı'ndan bu ihtimali göz ardı etmeden hazırlıklarını tamamlamasını istedi ${ }^{91}$. Bu arada esirlerin iç vilayetlere sevkinde önemli bir konumda olan 12. Kolordu Komutanlığı'na da hazırlıklarını kısa sürede tamamlaması emredildi ${ }^{92}$.

Harbiye nezareti 16 Kasım'da yeni bir girişimde bulunarak "20.000 esirin icap eden teslim ve iaşe tertibatının esaslı yapılabilmesi için istikamet-i sevkleri hakkında tayin edilen neticenin" bildirilmesini talep etti ${ }^{93}$. İngiliz irtibat subaylığından 16 Kasım'da verilen cevap güzergah konusunda

\footnotetext{
${ }^{90}$ ATASE, İSH, K.100, G.47, B.47-3,4.

${ }^{91}$ ATASE, ISH, K.100, G.47, B.47-1.

${ }^{92}$ ATASE, ISH, K.100, G.47, B. 47-5.

${ }^{93}$ ATASE, ISH, K.100, G.47, B.47-2.
} 
henüz kesin bir karar alınmadığını ortaya koyuyordu. İrtibat subayı Dean Millence, Nusaybin ile ilgili teklifin incelendiğini beyanla İtilaf makamları arasında kesin bir karar alınması halinde Türk makamlarının bilgilendirileceğini vaat etti ${ }^{94}$.

13. Kolordu Komutanlığı, Cizre'de teslimin yapılacağından hareketle burada bir Sevk Komisyonu teşkil etmiş ve bulaşıcı hastalıklarını kontrol altında tutmak için bir bakterilogu bölgeye göndermişti. Zayıf bir ihtimal de olsa Nusaybin'de yapılacak teslimatta sorun yaşanmaması için 5. Tümen Komutanlığı'na gereken talimat verilmişti. Miralay Cevdet Bey, menzil teşkilatlarının bir çoğunun Fransız işgal bölgesi içerisinde kaldığına dikkat çektiği telgrafında bu hususun iç vilayetlere sevklerde sorunlar doğuracağını belirterek Fransız makamlarının anlayışlı davranmaları için girışsimde bulunulmasını istedi ${ }^{95}$. Bu talep üzerine Harbiye Nezareti, Fransızlarla ilgili olarak İngiliz Karadeniz Orduları Başkomutanlığı nezdinde girişimde bulundu. 22 Kasımda kolorduya gönderilen telgrafta konuya ilişkin olarak şu ifadelere yer veriliyordu:

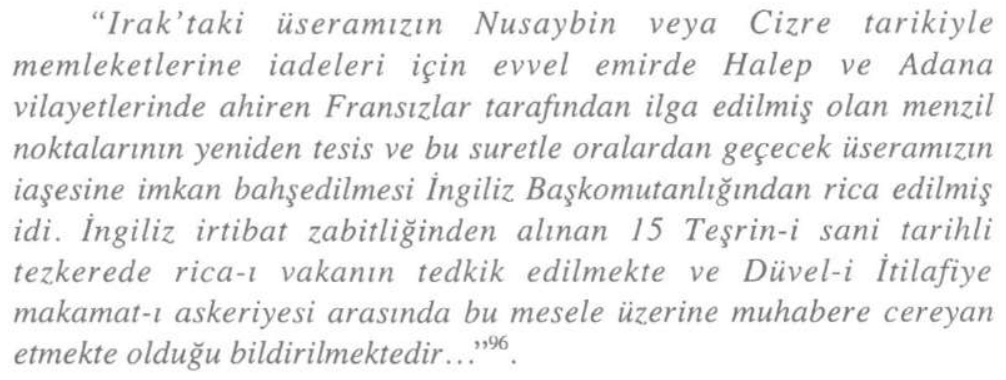

Harbiye Nezareti iki gün sonra gönderdiği telgrafta ise Irak'taki İngiliz Ordusu Başkomutanlığı'nın Türk esirlerini Musul ile Nusaybin arasındaki Yülek bölgesinde teslim etmeyi teklif ettiği ve adı geçen bölgenin sınır dışında suyu bulunan en uygun menzil noktası olduğunun iddia edildiğini belirterek bir yandan cevap verilmesini, diğer yandan da İngilizlerin tekliflerini hayata geçirmeleri kuvvetle muhtemel gördüğünden bölgeyle ilgili istihbaratta bulunulmasinı emretti ${ }^{97}$.

Bütün yazışmalar göz önüne alındığında İngiliz makamlarının henüz bir sevk programı belirlemedikleri anlaşılıyordu. Önce Cizre, arkasından Nusaybin ve şimdi Yülek adını öne çıkarmaları bunu gösteriyordu. Esasında bu teklifler Irak'taki İngiliz Orduları Başkomutanlığı'nın sevke dair bir hazırlığının da bulunmadığını gösteriyordu. Aksi takdirde iki aydır hareketsiz kalınması başka türlü açıklanamazdı.

\footnotetext{
${ }_{95}^{94}$ ATASE, ISH, K.237, G.70, B.70-1.

${ }^{95}$ ATASE, ISH, K.100, G.53, B. 53-3,2

${ }^{96}$ ATASE, ISH, K.100, G.53, B.53-4.

${ }^{97}$ ATASE, ISH, K.100, G.53, B.53-1.
} 
Cevdet Bey değerlendirmelerini içeren 27 Kasım tarihli telgrafında; İngilizlerin teklif ettikleri bölgenin Nusaybin'den 110, Demirkapi'dan 50, Musul'dan takriben $100 \mathrm{~km}$. uzaklıkta ve Musul-Nusaybin hattı dışında kaldığını, menzil kollarının bu güne adı geçen bölgede herhangi bir hareketinin olmadığını, haritaların incelenmesi durumunda civarında iskan ve iaşeyi temin edecek köylerin bile bulunmadığını, şiddetli yağmurların başladığı bu hat üzerinde araba işletmek imkansızlaştı̆̆ından Cizre'den buraya erzak vs. sevkinin mümkün olmadığını, erzağın satın alma yoluyla ancak Nusaybin'den tedarik edilebileceğini, fakat binlerce esir için develer ve mekkareler kullanılmasının ve haberleşmenin temin edilemeyeceğini, Nusaybin'e kadar $110 \mathrm{~km}$ 'lik hat üzerinde yeniden menzil teşkil etmek ve bir çok karakol kurmanın zor olduğuna dikkat çekerek esirlerin Zaho-Cizre arasında Görgit mevkiinde yada Musul-Nusaybin yolu üzerinde Demirkapı mevkiinde teslim edilmesini istedi. Cevdet Bey'e göre Demirkapı civarında köyler olduğundan ve Nusaybin'den erzak sevki de kolay olduğundan iskan ve iaşede sorun yaşanmayacaktı. Üstelik İngilizler de hurma ve peksimet vererek esirleri Demirkapı'ya kadar sevk etmekte zorluk çekmeyeceklerdi. Kafilelerin biner kişiden fazla olmamasına iskan ve iaşenin düzeni açısından önemli olduğuna dikkat çeken Cevdet Bey, kolordunun Islahiye'ye kadar hizmet vereceğini, bundan sonrasının ise Nezaretçe temin edilmesi gerektiğini belirtti ${ }^{98}$.

Harbiye Nezareti de 1 Aralıkta General Milne'ye hitaben gönderdiği yazıda; Cevdet Bey'in uyarılarını özet halinde sıralayarak esirlerin her şeyden mahrum olan bir bölge yerine Zaho-Cizre arasında Görgit mevkiinde yada Musul-Nusaybin yolu üzerinde Demirkapı mevkiinde teslim edilmesini önerdi ${ }^{99}$.

İngilizler sevkıyata başlamaları gerekirken, Türk tarafını ilgilendiren küçük sorunları gündeme getirmeye devam ediyorlardı. İngiliz irtibat subayı Millence, 18 Aralıkta esirlerin Nusaybin demiryolundan yararlanmalarına bir engel olup olmadığını öğrenmek isteyince aynı gün Nezaret, esirlerin Demirkapı ve Görgit mevkilerinde teslimlerinin trenden yararlanmalarına engel olmadığını, ancak trenle sevk edilirken iaşelerinin temini için Adana ve Katma'da Osmanlı menzil merkezlerinin yeniden kurulmasına ihtiyaç duyulduğunu ifade ederek adı geçen demiryolu hattının Fransızlara teslim edildiğini nakliyatın önceden Fransızlarla ortak tanzim edilebilmesi için iadeye ne zaman başlanacağının bildirilmesini talep etti ${ }^{100}$.

Harbiye Nezareti ile İngiliz makamları arasında bu görüşmeler sürerken 13. Kolordu Komutanlığı Adana Demiryolu Komisyonu nezdindeki girişiminden olumlu sonuç aldı. Buna göre; trenler Mardin'den Konya'ya

${ }^{98}$ ATASE, İSH, K.100, G.56, B.56-4.5

${ }^{99}$ ATASE, ISH, K.100, G.56, B.56-2,3

${ }_{100}$ ATASE, ÍSH, K.117, G.46, B.46-4,3; Bu yazışmaya bağlı olarak Levazımat Dairesi'ne de esirlerin iskan ve B. $46-1,2$ )

iaşeleri hususunda önlemleri eksiksiz alması emredildi (ATASE, ISH, K.117, G.46, 
hareket ederken askerler iki günlük iaşelerini yanlarına alacak, her trene muhafız olarak 1 subay ile 20 silahlı er bindirilecekti. İlk tren 15 Ocak 1920 'de Mardin'den yola çıkacaktı. Teslim tarihi belli olduğunda kolordunun talebi üzerine tren gönderilecekti. Bölgenin asayiş durumu dikkate alınarak kolordu tarafından muhafız tahsis edilemeyeceğinden esirler arasından uygun olanlara Konya'da teşkil edilmek üzere her bir tren için 20 silahın verilmesine karar verildi ${ }^{101}$.

13. Kolordu Komutanlığı'nın hazırlıkları son aşamasına getirmesine karşın İngilizlerden kesin bir bilgi alınamaması Harbiye Nezareti'ni ve kolorduyu sıkıntıya sokuyordu. Yaklaşık 4 ay süren yazışma ve hazırlıkların ardından General Milne'nin 26 Şubat 1920'de gönderdiği mektup, esirlerin iadesi hususunda son aşamaya gelindiğini gösteriyordu. General Milne, Irak Ordusu Başkomutanlığı'ndan aldığı bilgiye dayanarak, İngiliz tarafında hazırlıkların tamamlandığını, her hafta veya uygun aralıklarla biner kişilik esir kafilelerinin nakledileceğini Görgit'deki Osmanlı memurlarına teslim edileceğini bildirdi ${ }^{102}$. Harbiye Nazırı Fevzi Paşa tarafından memnunlukla karşılanan mektuba 1 Martta verilen cevapta ilk kafilenin hareket tarihine ilişkin alınacak bilginin zaman geçirilmeksizin kendilerine ulaştırılmasını talep etti ${ }^{103}$. Ayrica Nezaret 6 Martta 12. ve 13. Kolordu Komutanlıklarını kafilelerin her an yola çıkarılacağı hususunda uyararak karşıllanmaları ve sevkleri için gereğinin yapılmasını emretti ${ }^{104}$.

\footnotetext{
${ }^{101}$ ATASE, İSH, K.117, G.45, B.45-2; ATASE, İSH, K.202, G.232, B.232-1.

${ }^{102}$ ATASE, ISH, K.117, G.66, B.66-4.

${ }^{103}$ ATASE, ISH, K.117, G.66, B.66-5.

${ }^{104}$ ATASE, ISH, K.117, G.66, B.66-1.
} 